\title{
Rapid Isolation of Bacteriophages: Steps Towards Phage Therapy
}

\author{
Idah Sithole-Niang*, Shamiso Muchayi and Anna Mashonganyika \\ Professer, Department of Biochemistry, University of Zimbabwe, Harare, Zimbabwe \\ *Corresponding Author: Idah Sithole-Niang, Professer, Department of Biochemistry, University of Zimbabwe, Harare, Zimbabwe.
}

Received: April 01, 2019; Published: June 07, 2019

DOI: 10.31080/ASPS.2019.03.0308

\section{Introduction}

With the advent of antimicrobial resistance worldwide, there is renewed interest in studying bacteriophages and using them as a possible source of controlling raging bacterial infections. This approach is known as phage therapy and is attracting renewed interest as a topic of study. Bacteriophages are viruses that infect bacteria. Bacteriophages, phages for short, are the most abundant organisms in the biosphere, approaching an estimate of $\sim 10^{31}$ particles in total. They can be found in soil, wastewater and sewage. In this protocol phages can be isolated from virtually any source by using bacteria to fish them out. Initially waste water is collected from a point source then the phages are enriched using a suitable bacterial host strain such as Escherichia coli or indeed any microorganism that is found in sewage especially, such as Staphylococcus aureus, Klebsiella sp, Campylobacter sp or Pseudomonas sp. The phage is enriched by inoculating an overnight culture and growing it $37^{\circ} \mathrm{C}$ overnight with shaking.

The phage is then harvested in $1 \mathrm{ml}$ aliquots by centrifugation at $12 \mathrm{~K} \mathrm{rpm}$ for 5 mins and the supernatant is passed through a $0.22 \mathrm{u}$ filter into a sterile microfuge tube. Three drops of chloroform are then added to lyse any renaming bacteria and also help with long term storage of the phage. At this point the page is titered by inoculating different amount of the phage with $1 \mathrm{ml}$ of host bacterium and $3 \mathrm{ml}$ of sterile top agarose ( $0.7 \%$ agarose), mixed thoroughly by vortexing and palting onto fresh LB plates. This is incubated at $37^{\circ} \mathrm{C}$ overnight. On the following day, one should be able to observe plaques, which are zones of clearing due to lysis of the host bacterium. If the plaques are well separated, then the phages can be picked using a Pasteur pipette fitted with a bulb. The plaque is then deposited in $1 \mathrm{ml}$ of sterile buffer containing $10 \mathrm{mM}$ Tris (pH 8.00 and $1 \mathrm{mM}$ EDTA (pH 8.0) also known as TE buffer ( $\mathrm{pH}$ 8.0). The plaques are allowed to diffuse out of the agar plug and then stored with a drop of chloroform. This phage is then used to inoculate another round of infection overnight so that a large quantity of phage can be harvested and purified. This is done by flooding the plate with $2 \mathrm{ml}$ sterile TE (pH 8.0) and gentle rocking of the plate on a shaker. After an hour the solution is then harvested and clarified by centrifugation at $5 \mathrm{~K} \mathrm{rpm}$ for 2 min. The supernatant is the phage prep that is stored with a drop of chloroform indefinitely.

The genomic DNA is isolated from phage using a lysis buffer (100 mM Tris:HC pH 8.0, $150 \mathrm{mM}$ Sodium chloride, $60 \mathrm{mM}$ EDTA and $1 \%$ SDS).To a $2 \mathrm{ml}$ microfuge tube is added $800 \mathrm{ul}$ of phage prep and $800 \mathrm{ul}$ of Lysis buffer and mix by inversion, then add $20 \mu \mathrm{l}$ of Proteinase $\mathrm{K}(20 \mathrm{mg} / \mathrm{ml})$ is added incubated at $55^{\circ} \mathrm{C}$ for $30 \mathrm{~min}$. The lysate is centrifuged at $10 \mathrm{~K} \mathrm{rpm}$ for $10 \mathrm{~min}$ at room temperature. Transfer $800 \mu \mathrm{l}$ of supernatant to two fresh $1.5 \mathrm{ml}$ tubes and $80 \mu \mathrm{l}$ of 3M Sodium acetate $\mathrm{pH}$ (5.2) is added to each tube and another equal volume of isopropanol $(800 \mu \mathrm{l})$ is also added and mixed by inverting the tube 3 - 4 times. The mixture is centrifuge at $10 \mathrm{~K}$ for $10 \mathrm{~min}$ at RT and the supernatant is decanted and the tubes are well drained. The DNA pellet is washed with addition of $1 \mathrm{ml}$ of ice-cold $70 \%$ ethanol and centrifuged at $10 \mathrm{~K}$ for $3 \mathrm{~min}$. The supernatant is discarded and the pellet is dried in a Speedvac for 10 minute. The pellet is resuspended in $50 \mu \mathrm{l}$ of TE buffer and use accordingly either for gel electrophoresis or down-stream processing.

\author{
Volume 3 Issue 7 July 2019 \\ (C) All rights are reserved by Idah Sithole-Niang., et \\ al.
}

